\title{
The Spectrum of Infections by Fusarium Species on Codiaeum Variegatum (L.) Blume Cultivars as Influenced by Fructose Specific Lectin
}

\author{
O. A. Awoyinka ${ }^{1, *}$, C. N. Ezekiel', E. B. Es an ${ }^{2}$, C. G. Afolabi ${ }^{3}$, O. Z. Ikokide ${ }^{1}$, A. Bankole ${ }^{2}$, O. S. Bada ${ }^{1}$, \\ O. E. Ogheneovo ${ }^{2}$
}

\author{
${ }^{1}$ Department of Biochemistry, Benjamin Carson's (Snr.) College of Medicine, Babcock University, Ilishan Remo, Nigeria \\ ${ }^{2}$ Department of Biosciences and Biotechnology, Babcock University, Ilishan Remo, Nigeria \\ ${ }^{3}$ Department of Crop Protection, Federal University of Agriculture, Abeokuta, Nigeria
}

\begin{abstract}
This study sought to have an insight into the mechanism of action of diseases responsible for the susceptible Codiaeum variegatum (garden croton) leaves induced by Fusarium species and the clinical importance of the disease resistant types. The plants were obtained from the Babcock University Germplasm Repository. Therefore, phytopathogenic Fusarium species were isolated from three diseased susceptible cultivars of C. variegatum (ovalifolium, royal-like and punctatum). Accordingly, lect in was isolated, purified and characterized from the leaves of a resistant garden croton cultivar (royal), and further evaluated for antifungal activity using isolates of Fusarium lateritium and F. semitectum obtained from the three diseased cultivars. The heamagglutinating activity of the purified lect in was non selective to type of blood group (A, $\mathrm{B}, \mathrm{AB}$ and $\mathrm{O}$ ) and was inhibited by fructose, sialic acid, and copper sulphate, but was enhanced by galactose, calcium chloride, sodium chloride and magnesium chloride. Optimum heamagglutinating activity of the lectin was achieved at $30-40^{\circ} \mathrm{C}$ and $\mathrm{pH}$ 5.0-6.0. The lectin exhibited antifungal activity against the two Fusarium species in a non-concentration dependent manner. It is therefore concluded that Fusarium species are major phytopathogens of the garden croton plant and their spectrum of pathogenicity is dependent on the presence or absence of lectins. In addition, the resistant cultivar of $C$. variegatum (cv. royal) used in this study may be a suitable candidate for the prevention and treatment of fungal infections.
\end{abstract}

Keywords Codiaeum variegatum, Fusarium, Fructose, Galactose, Lectin, Systemic Acquired Resistance, Phytoallexins, Signal Transduction Pathway

\section{Introduction}

Lectins are carbohydrate-binding proteins that bind reversibly and possess the ability to agglutinate cells or precipitate polysaccharides and glyco-conjugates. They are widely distributed in animals, plants and microorgan isms and have attracted great interest due to their various biological activities, such as cell agglutination, anti-tumor, immuno-modulatory, antifungal, antiviral and anti insect activities(1-2). Recent studies in glycobiology have emphasized lectins as the prime tools for cell-to-cell recognition in interactions involving numerous pathogens such as viruses, fungi, bacteria and the pluricellular parasites. The lectins recognize and bind to the oligosaccharides exposed by target cells and tissues thereby leading to the establishment of an infection (3). Conversely, the pathogen

* Corresponding author:

awoyinkao@babcockuni.edu.ng (O. A. Awoyinka)

Published online at http://journal.sapub.org/ijmb

Copyright (C) 2012 Scientific \& Academic Publishing. All Rights Reserved surfaces bear a large number of oligosaccharides that may be bound by specific lectins which can modulate the host infection (4-5).

These carbohydrates may be covalently bound, as in glycosylated teichoic acids to peptidoglycan, or non-covalently bound, as in capsular polysaccharides. Every surface-exposed carbohydrate is a potential lectin-reactive site. The ability of lectins to selectively form complexes with microbial glyco-conjugates makes them useful investigative tools for host-pathogen interaction. In the natural environment, microorganisms interact with each other to maintain their growth, development and stability within ecosystem. The interaction process can only be revealed by understanding the fundamentals of ecological relationships of diverse microbial population including pathogens and antagonists. In many instances, physical attachment of microorganisms is mediated by specific compatible macro molecules. The specific interaction between microbial populations may play a key role for successful establishment, persistence and colonization (6-7). The role of cell surface macromolecules, potential ligands and receptors of cell 
surface agglutinins or lectins as recognition factor during attachment of two interacting partners, are well known (89).

Previous studies on the Codiaeum variegatum cultivars in the Germplasm Repository of Babcock University have associated some Fusarium species with the increased disease conditions of this ornamental plant (10-11). However, no study has been carried out to investigate the mechanism of disease occurrence in cultivars members of the plant. In the present study, lectin purified from a disease resistant croton cultivar in the germplasm repository was partially characterized and evaluated for antifungal activity using two Fusarium species isolated from three other diseased susceptible cultivars of the garden croton ornamental plant.

\section{Materials and Methods}

\subsection{Collection of Plant Materials}

The leaves (diseased and non diseased) of four Codiaeum variegatum (garden croton) cultivars (C. variegatum $\mathrm{cv}$. royal, $C$. variegatum $\mathrm{cv}$. ovalifolium, $C$. variegatum $\mathrm{cv}$. royal-like and C. variegatum cv. punctatum) (Fig. 1) were collected from the horticultural garden of Babcock University Germplas m Repository (BUGR), Ilishan-Remo, Nigeria. Field botanical characterization and identification of the cultivars was carried out by one of the authors who is a Plant Scientist and Biotechnologist in charge of the BUGR. Codiaeum variegatum cv. royal was collected as the resistant cultivar while $C$. variegatum cv. ovalifolium, C. variegatum $c v$. royal-like and $C$. variegatum $c v$. punctatum were obtained as the susceptible cultivars. The cultivars were placed in clean polythene bags and transported to the Microbiology laboratory of Babcock University for further analysis.

\subsection{Isolation and Char acterization of Leaf-Borne Fusarium in Garden Croton Cultivars}

Leaf-borne Fusarium was isolated according to the method described by Dubey \& Maheshwari (2006). Diseased leaves of each cultivar of garden croton were surface sterilized for 3 minutes in $2 \%$ sodium hypochlorite. The sterilized leaves were rinsed in two changes of sterile distilled water and blotted dry in two fo lds of Whatman No. 1 filter paper. Two $3 \mathrm{~mm}$ discs each were obtained from the visibly infected and uninfected regions of the leaves of a cultivar, and plated out on peptone-pentachloronitrobenzene agar (PPA), a semi selective medium for Fusarium (13). Each set of two discs from the infected region was placed along the dia meter line of the PPA p late at $3 \mathrm{~cm}$ distance from each other. This was repeated for the discs from the uninfected region of the same cultivar. The set up was replicated thrice for each cultivar and all the inoculated plates were incubated for 3 days under fluorescent lights on a $12 \mathrm{~h}$ day/ night schedule at $22-24^{\circ} \mathrm{C}$.

After 3 days, morphologically distinct colonies of
Fusarium species that emerged from the leaf discs were transferred to $1 / 4$ strength potato dextrose agar (PDA) and incubated for 5 days as described above. Single spore was started for each isolate by micromanipulation on $2 \%$ water agar and the plates were incubated overnight at $22-24^{\circ} \mathrm{C}$. The germlings were sub cultured from water agar and maintained on a modified Czapek's-Dox complete medium (CM). This was stored at $4^{\circ} \mathrm{C}$ prior to identification. Each isolate was further sub cultured from $\mathrm{CM}$ onto carnation leaf agar (CLA for examination of sporodochia and uniform macro conidia under the Olympus BX51 Digital Microscopy, Olympus Optical Co., LTD, Japan) and full strength PDA (for pigmentation and colony morphology evaluation). The plates were incubated as above for 10-14 days. Morphological identification of the Fusarium species was performed as described by Leslie \& Summerell(2006).

\subsection{Pathogenicity Testing of Fusarium Is ol ates on Gar den Croton Leaves}

The pathogenicity of each Fusarium isolate obtained from the diseased parts of the croton leaves was tested by adopting the Koch's postulate as modified and reported by Dubey \& Maheshwari (2006). About 20 young uninfected leaves were obtained from the ap ical parts of each cultivar and surface sterilized for 3 minutes in $2 \%$ sodium hypochlorite. The sterilized leaves were rinsed in two changes of sterile distilled water and blotted dry in two fo lds of Whatman No. 1 filter paper. Mild abrasions along the veins of each young uninfected leaf were induced using a sterile toothpick. Thereafter $0.1 \mathrm{ml}$ spore suspension containing $10^{6}$ spores $/ \mathrm{mL}$ of each corresponding Fusarium isolate was spread over the abrasions using a sterile cotton bud. Each inoculated leaf was placed on a moistened filter paper in a Petri dish which has been under-layed with cotton wool. All Petri dishes were incubated at ambient temperature for 5 days and the leaves were observed daily for symptoms of the disease on the inoculated part of the leaves. The diseased parts of the inoculated leaves were obtained, surface sterilized and plated on to $1 / 4$ strength potato dextrose agar (PDA). After a 5-day incubation period at $22-24^{\circ} \mathrm{C}$ the associated Fusarium isolates were identified macroscopically and microscopicall $y$ following the procedures reported earlier.

\subsection{Blood Samples}

Five milliliter each of 10 human blood samples of different blood groups (A, B, AB and O) was collected from Babcock University Medical Laboratory, Ilishan-Remo, Nigeria. The blood samples were collected in heparinised bottles containing (ethylene diamine tetra acetate, EDTA) to prevent coagulation and kept at $4^{\circ} \mathrm{C}$ prior to analysis.

The blood samples were treated as described by Lis et al. (1994). Briefly, $5 \mathrm{~mL}$ of each sample was centrifuged at 1500 $\times \mathrm{g}$ for 5 minutes at ambient temperature. The red blood cells obtained were then washed by centrifugation at $1500 \times \mathrm{g}$ for 5 minutes at ambient temperature with $0.01 \mathrm{M}$ phosphate-buffered saline (PBS, pH 7.2). This was repeated 
twice and the resulting cells were mixed with $3 \%$ formaldehyde in EDTA bottle and allowed to stir gently overnight prior to further centrifugation at $1500 \times \mathrm{g}$ for 5 minutes. The centrifuged blood cells were washed again as stated earlier, three times with $0.01 \mathrm{M}$ PBS $(\mathrm{pH}$ 7.2) and the cells were collected into a stopped bottle. About $76.8 \mathrm{~mL}$ of $0.01 \mathrm{M}$ PBS was added to dilute the concentration of the cell. This concentration was then stored at $4{ }^{\circ} \mathrm{C}$ prior to further analys is.

\subsection{Isolation and Purification of Lectin from $C$. Variegatum Leaves}

Lectin was isolated and partially purified from $C$. variegatum $c v$. royal according to the procedures described by Awoyinka \& Dada (2011) with slight modification. The leaves were pulverized and defatted using chloroformacetone in ratio 2:1 thereafter the defatted samples were dissolved in distilled water $(1: 20 \mathrm{v} / \mathrm{v})$. An aliquot of the mixture was separated using Whatman filter paper and kept in refrigerator for carbohydrate analys is, while the other part was centrifuged at $1500 \times \mathrm{g}$ for 30 minutes. Pellets were obtained and discarded while the supernatant was collected for ammonium sulphate precipitation as described by Trowbridge (1974). The precipitated protein were pulled together and dissolved in $240 \mathrm{ml}$ of distilled water, the resulting mixture was concentrated by ultra-filtration (Millipore, India) at $1500 \mathrm{~g}$ for 30 minutes before dialyses against $0.15 \mathrm{M} \mathrm{NaCl}-0.01 \mathrm{M} \mathrm{NaPO}_{4}$ buffer for 24 hours. The dialyzed sample was then collected in an empty bottle and stored at $4^{\circ} \mathrm{C}$ prior to assay for lectin activity.

\subsection{Assay for Lectin Activity}

Agglutination of red blood cells by the extract and the various fractions that were obtained during the purification steps was determined as described by Bing et al. (1967). A serial two-fold dilution of the lectin solution was mixed with $50 \mu \mathrm{L}$ of a $4 \%$ suspension of human erythrocytes in PBS $(\mathrm{pH}$ 7.2), at ambient temperature. The erythrocytes of human blood group $\mathrm{A}, \mathrm{B}$ and $\mathrm{O}$ were fixed with $3 \%$ formaldehyde. The plate was left undisturbed for 60 minutes at ambient temperature in order to allow the agglutination of erythrocytes to take place. The heamagglutination titre of the lectin expressed as the reciprocal of the highest dilution exhibiting visible agglutination of erythrocytes was reckoned as one heam agglutination unit. Specific activity was expressed as the number of heamagglutination units per microgram protein (19).

\subsection{Anti-Fungal Sensitivity Assay}

The in vitro sensitivity of the is olated Fusarium species to the partially purified lectin was determined according to a modified disc diffusion method for antibacterial assay (20). Each Fusarium isolate was inoculated at the center of a $9 \mathrm{~cm}$ Petri dish containing freshly prepared PDA and incubated at $22-24^{\circ} \mathrm{C}$ for 3 days under a 12-hour light/darkness schedule. Four pieces of $3 \mathrm{~mm}$ sterile paper discs were placed on the four cardinal points of the growing culture at distances of $0.5 \mathrm{~cm}$ away from the boundary of the colony so as to give a square. Each of the four discs in a Fusarium culture was moistened with $5 \mu \mathrm{L}$ of the partially purified lectin suspension. This procedure was performed for the $10 \mu \mathrm{L}$ and $20 \mu \mathrm{L}$ treatments of paper discs in a Fusarium culture with the partially purified lectin. All cultures were treated in triplicates for each lectin treatment. Two sets of triplicate control plates were set up by impregnating the paper discs with $20 \mu \mathrm{L}$ of $0.15 \mathrm{M} \mathrm{NaCl}$ in one set and $5 \mu \mathrm{L}$ of sterile distilled water in the other. The plates were then incubated as stated above for 4 additional days. The zones of inhibition were measured daily for 4 days.

\subsection{Inhibition of Lectin-induced Heamagglutination by Various Carbohydrates}

The ability of various carbohydrates to inhibit lectin-induced heamagglutination was investigated using a procedure that is analogous to the heamagglutination test described by Kuku et al. (2009). The sugars used were glucose, galactose, maltose, fructose, sucrose, lactose, raffinose, trehalose and sialic acid. Serial two-fold dilutions of each sugar sample were prepared in PBS. All the dilutions were mixed with an equal volume $(50 \mu \mathrm{L})$ of the lectin solution of known heamagglutination units. The mixture was allowed to stand for 60 minutes at ambient temperature and then mixed with $50 \mu \mathrm{L}$ of a $4 \%$ human erythrocyte suspension. The heamagglutination titres obtained were compared with a non-sugar containing blank. The minimum concentration of the sugar in the final reaction mixture which completely inhibited heamagglutination units of the lectin sample were obtained (19).

\subsection{Effect of salts on Heamagglutinating Activity of Lectin}

Nine salts [calcium chloride, $\mathrm{CaCl}_{2}$; iron (III) sulphate, $\mathrm{Fe}_{2}\left(\mathrm{SO}_{4}\right)_{3}$; ferric chloride, $\mathrm{FeCl}_{3}$; sodium sulphate, $\mathrm{Na}_{2} \mathrm{SO}_{4}$; copper sulphate, $\mathrm{CuSO}_{4}$; magnesium chloride, $\mathrm{MgCl}_{2}$; sodium chloride, $\mathrm{NaCl}$; potassium chloride, $\mathrm{KCl}$; potassium phosphate, $\mathrm{KH}_{2} \mathrm{PO}_{4}$ ] were evaluated for their inhibitory ability against heamagglutination induced by lectin. Serial two-fold dilutions of salt samples were prepared in PBS. All the dilutions were mixed with an equal volume $(50 \mu \mathrm{L})$ of the lectin solution of known heamagglutination units. The mixture was allowed to stand for 60 minutes at ambient temperature and then homogenized in $50 \mu \mathrm{L}$ of a $4 \%$ human erythrocyte suspension. The heamagglutination titres obtained were compared with a non-salt containing blank. The minimum concentration of the salt in the final reaction mixture which completely inhibited heamagglutination units of the lectin sample were obtained (19).

\subsection{Effect of Temperature on Heamagglutinating Activity of Lectin}

The method of Patrick et al. (2007) was adopted for testing the effect of various temperature regimes on the 
agglutinating activity of lectin obtained from croton. The purified lectin was incubated in a water bath for 30 minutes at various temperatures: $-10,-4,10,20,30,40,50,60,70,80$, 90 and $100^{\circ} \mathrm{C}$, and then cooled to $20^{\circ} \mathrm{C}$. Hea magglutination assay was carried out as previously described.

\subsection{Effect of pH on Heamagglutinating Acti vity of Lectin}

The effect of different $\mathrm{pH}$ regimes $(2,3,4,5,6,7,8,9,10$, 11 and 12) on the activity of lectin obtained from croton was determined by incubating the lectin in the buffers of different $\mathrm{pH}$ values. The $\mathrm{pH}$ values of $0.15 \mathrm{M} \mathrm{NaCl}-0.01 \mathrm{M} \mathrm{NaPO} 4$ buffer were altered using concentrated $\mathrm{HCl}$ and $1 \mathrm{M} \mathrm{NaOH}$, and assaying for heamagglutinating activity. The control values were the agglutination titre of the lectin in PBS $(\mathrm{pH}$ 7.2).

\section{Results}

As a result of initial field observations carried out so as to determine the magnitude and severity of the infection by the Fusarium species, the cultivars of the garden croton have been described and categorized into THREE: namely, heavily susceptible (A), resistant (B) and tolerant (C) cultivars. In the category "A" the pathogen kills aborts the leaves and kills the twigs; whilst in the category "B" no signs of pathogenicity was observed. However, in the category "C" only necrotic leaf spots which do not spread or coalesce was the case. The leaves of Codiaeum variegatum cv. royal showed no growth of Fusarium while the diseased leaf discs of $C$. variegatum $\mathrm{cv}$. ovalifolium, $C$. variegatum $\mathrm{cv}$. royal-like and C. variegatum cv. punctatum showed growths of Fusarium species (Fig. 2). The isolates obtained from $C$. variegatum $c v$. ovalifolium were identified as $F$. semitectum and $F$. lateritium while those from $C$. variegatum $c v$. royal-like and $C$. variegatum $c v$. punctatum were all $F$. lateritium.

Lectin from $C$. variegatum $c v$. royal was found to agglutinate human erythrocytes and showed an activity that was non-selective to type of blood group (A, B, A B and O). The three concentrations of lectin exhibited antifungal activity towards all Fusarium isolates by inhibiting hyphal growth of the test isolates while the controls $(\mathrm{NaCl}$ and sterile distilled water) had no inhibitory effect on the isolates (Fig. 4). The data obtained from the studies for the inhibitory effects of different sugar concentrations on lectin activity of C. variegatum cv. royal lectin are presented in Table 1. It was observed that all concentrations of maltose, lactose and sucrose had no inhibitory or stimulatory effect on heamagglutinating activity of the lectin. The 100 and 200 $\mathrm{mM} / \mathrm{L}$ glucose concentrations enhanced agglutination of human erythrocytes more than other concentrations of the sugar while the highest concentration of $800 \mathrm{mM} / \mathrm{L}$ resulted in a complete loss of heamagglutination activity. In the presence of very low $(25 \mathrm{mM} / \mathrm{L})$ and very high (400 and $800 \mathrm{mM} / \mathrm{L}$ ) galactose concentrations, we observed an increased binding of the lectin to human erythrocytes. On the other hand, fructose, trehalose and sialic acid did not inhib it or stimulate heamagglutination at very low concentration of $25 \mathrm{mM} / \mathrm{L}$, but showed a complete inhibition of the lectin's heamagglutination activity at higher concentrations of $100-800 \mathrm{mM} / \mathrm{L}$ sugar. At concentrations of $50-200 \mathrm{mM} / \mathrm{L}$ raffinose, heamagglutinating activity of the lectin was completely lost while an increase of the concentration of raffinose to $400 \mathrm{mM} / \mathrm{L}$ enhanced the lectin's potential to bind to the red blood cells. Results similar to those observed in our study were reported by Perez (1995), who purified lectin fro m the seeds of Erythrina costarisencis.

The characterization and inhibition studies to define the salt specificities of lectin purified from $C$. variegatum $\mathrm{cv}$. royal (Table 2) showed that all concentrations of $\mathrm{Fe}_{2}\left(\mathrm{SO}_{4}\right)_{3}$ and $\mathrm{FeCl}_{3}$ did not inhibit or enhance the heamagglutinating potential of the lectin. On the contrary, the presence of $100-800 \mathrm{mM} / \mathrm{L} \mathrm{CuSO}_{4}$ co mp letely inhib ited heamagglutinat ion while the lower concentrations had no stimulatory effect either. The heamagglutinating potential of the lectin was at its peak in the presence of lower concentrations of $\mathrm{CaCl}_{2}$ and $\mathrm{NaCl}$, and as the concentrations reached $200 \mathrm{mM} / \mathrm{L}$ for $\mathrm{CaCl}_{2}$ and $400 \mathrm{mM} / \mathrm{L}$ for $\mathrm{NaCl}$ the activity reduced until no significant influence of the salt on lectin-binding activity was observed at $400-800 \mathrm{mM} / \mathrm{L} \quad \mathrm{CaCl}_{2}$ and $800 \mathrm{mM} / \mathrm{L} \mathrm{NaCl}$. Contrariwise is the higher stimulatory effect of increased concentrations of $\mathrm{MgCl}_{2} \quad(200-800 \mathrm{mM} / \mathrm{L})$ and $\mathrm{KCl}$ $(400-800 \mathrm{mM} / \mathrm{L})$ towards the agglutination of human erythrocytes by lectins. Similar results were reported on lectin extracted from the seeds of Cissus populnea (16).

Figure 5 shows the heamagglutinating activity of lectin obtained from $C$. variegatum $c v$. royal under different temperature regimes. It was observed that there was no heamagglutination activity at incubation temperature of $20{ }^{\circ} \mathrm{C}$ and below. However, a rapid increase in heamagglutination and consequent peak level of activity was reached at incubation temperature of $30-40^{\circ} \mathrm{C}$; this formed a plateau between the regimes. When the mix (lectin-erythrocytes) was incubated at higher temperatures $\left(50{ }^{\circ} \mathrm{C}\right.$ and above), a drastic reduction in activity was observed until the activity was completely lost at $80^{\circ} \mathrm{C}$ and above. This therefore indicates that ambient temperature is best suitable for the binding activity of this $C$. variegatum $\mathrm{cv}$. royal lectin. This finding is in contrast to that of the fructose-binding lectin purified from the gill of Aristichthys nobilis (24), where the lect in incubated at $50^{\circ} \mathrm{C}$ for $30 \mathrm{mins}$ showed agglutination that was fourfold stronger than when it was incubated at ambient temperature.

Data on the effect of $\mathrm{pH}$ on lect in activity are presented in Fig. 6. Lect in activity was stable at two $\mathrm{pH}$ ranges of 5.0-6.0 (acidic) and 9.5-10.5 (alka line). However, optimu mact ivity was recorded at $\mathrm{pH}$ range of 5.0-6.0. This result may therefore suggest that the protein has two binding sites; one site more active at a slightly acid ic $\mathrm{pH}$ range of 5.0-6.0 and the other at basic $\mathrm{pH}$ of 10.0. This finding is however, in contrast to that reported in which Manila clam lectin activity was stable between $\mathrm{pH} 6$ and $\mathrm{pH}$ 9, and was 
temperature-dependent (25). Our findings is also in contrast to other reports where $A$. nobilis lectin showed a decrease in agglutination activity on incubation at $\mathrm{pH} 6$ for $30 \mathrm{mins}$ therefore indicating its unstable nature under such conditions (24).

Table 1. Effects of sugar concentrations on the heamagglut inat ing act ivity of lectin from Codiaeum variegatum cv. royal lect in

\begin{tabular}{|c|c|c|c|c|c|c|c|}
\hline \multirow[b]{2}{*}{ Sugar } & \multicolumn{6}{|c|}{ Concentration of sugars in $\mathrm{mMol} / \mathrm{L}$} & \multirow{2}{*}{$\begin{array}{c}\text { Phosphate } \\
\text { Buffered } \\
\text { Saline }\end{array}$} \\
\hline & 25 & 50 & 100 & 200 & 400 & 800 & \\
\hline Maltose & + & + & + & + & + & + & + \\
\hline Lactose & + & + & + & + & + & + & + \\
\hline Sucrose & + & + & + & + & + & + & + \\
\hline Glucose & + & + & +++ & ++ & + & - & + \\
\hline Galactose & +++ & + & + & + & +++ & +++ & + \\
\hline Fructose & + & - & - & - & - & - & + \\
\hline Raffinose & + & - & - & - & ++ & + & + \\
\hline Trehalose & + & + & - & - & - & - & + \\
\hline Sialic acid & + & - & - & - & - & - & + \\
\hline
\end{tabular}

+ = agglutination $(5-50 \mathrm{Hu} / \mathrm{mg}) ;++=$ agglutination $(50-100 \mathrm{Hu} / \mathrm{mg}) ;+++=$ agglutination $(100 \mathrm{Hu} / \mathrm{mg}$ protein); - = No agglutination.

Table 2. Effects of salt concentrations on the heamagglutinating act ivity of Codiaeum variegatum cv. ryal lect in

\begin{tabular}{|c|c|c|c|c|c|c|c|}
\hline \multirow[b]{2}{*}{ Salt $^{\mathrm{a}}$} & \multicolumn{6}{|c|}{ Concentration of salts in $\mathrm{mMol} / \mathrm{L}$} & \multirow{2}{*}{$\begin{array}{c}\text { Phosphate } \\
\text { Buffered } \\
\text { Saline } \\
\end{array}$} \\
\hline & 25 & 50 & 100 & 200 & 400 & 800 & \\
\hline $\mathrm{CaCl}_{2}$ & +++ & +++ & +++ & ++ & + & + & + \\
\hline $\mathrm{Fe}_{2}\left(\mathrm{SO}_{4}\right)_{3}$ & + & + & + & + & + & + & + \\
\hline $\mathrm{FeCl}_{3}$ & + & + & + & + & + & + & + \\
\hline $\mathrm{Na}_{2} \mathrm{SO}_{4}$ & + & + & +++ & ++ & + & - & + \\
\hline $\mathrm{CuSO}_{4}$ & + & + & - & - & - & - & + \\
\hline $\mathrm{MgCl}_{2}$ & + & + & + & +++ & +++ & +++ & + \\
\hline $\mathrm{NaCl}$ & +++ & +++ & +++ & +++ & ++ & + & + \\
\hline $\mathrm{KCl}$ & + & + & + & + & ++ & +++ & + \\
\hline $\mathrm{KH}_{2} \mathrm{PO}_{4}$ & ++ & + & + & - & - & - & + \\
\hline
\end{tabular}

$+=$ agglutination $(5-50 \mathrm{Hu} / \mathrm{mg}) ;++=$ agglutination $(50-100 \mathrm{Hu} / \mathrm{mg}) ;+++=$ agglutination $(100 \mathrm{Hu} / \mathrm{mg}$ protein $)$ - = No agglutination.

${ }^{a} \mathrm{Salt}: \mathrm{CaCl}_{2}$, calcium chloride; $\mathrm{Fe}_{2}\left(\mathrm{SO}_{4}\right)_{3}$, iron (III) sulphate; $\mathrm{FeCl}_{3}$, ferric chloride; $\mathrm{Na}_{2} \mathrm{SO}_{4}$, sodium sulphate; $\mathrm{CuSO}_{4}$, copper sulphate; $\mathrm{MgCl}_{2}$, magnesium chloride; $\mathrm{NaCl}$, sodium chloride; $\mathrm{KCl}$, potassium chloride; $\mathrm{KH}_{2} \mathrm{PO}_{4}$, potassium phosphate
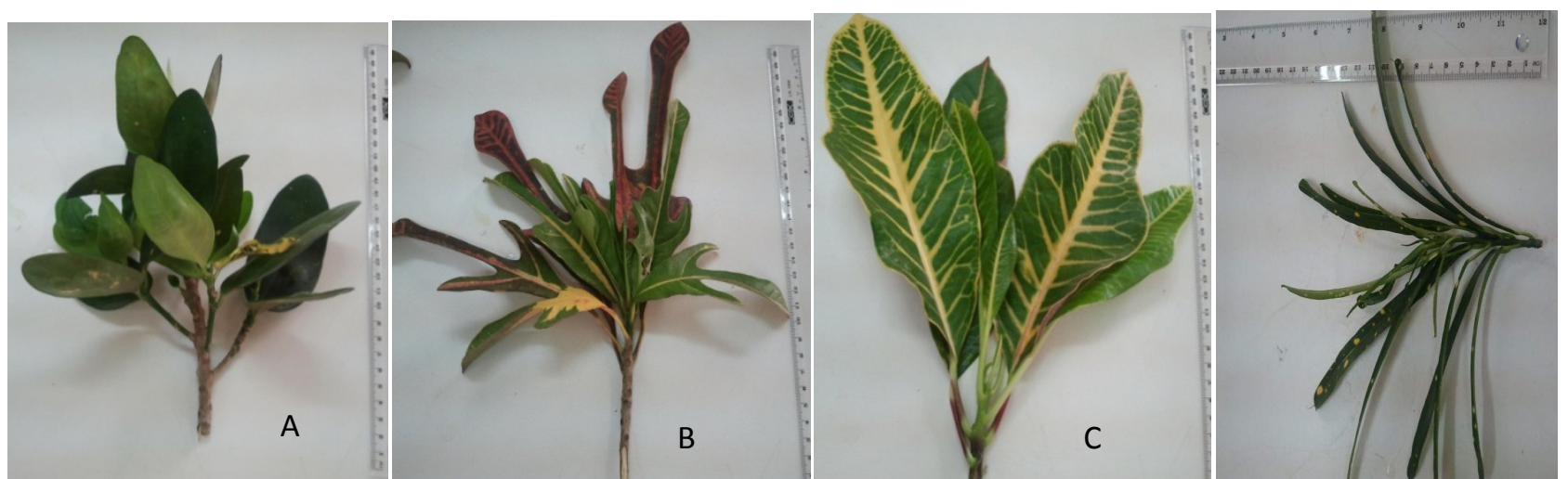

Figure 1. (A-D): Cultivars of Codiaeum variegatum used in this study. A) C. variegatum cv. royal B) C. variegatum cv. royal-like C) C. variegat um cv. punctatum D) C. variegatum cv. ovalifolium 
(L.) Blume Cultivars as Influenced by Fructose Specific Lectin
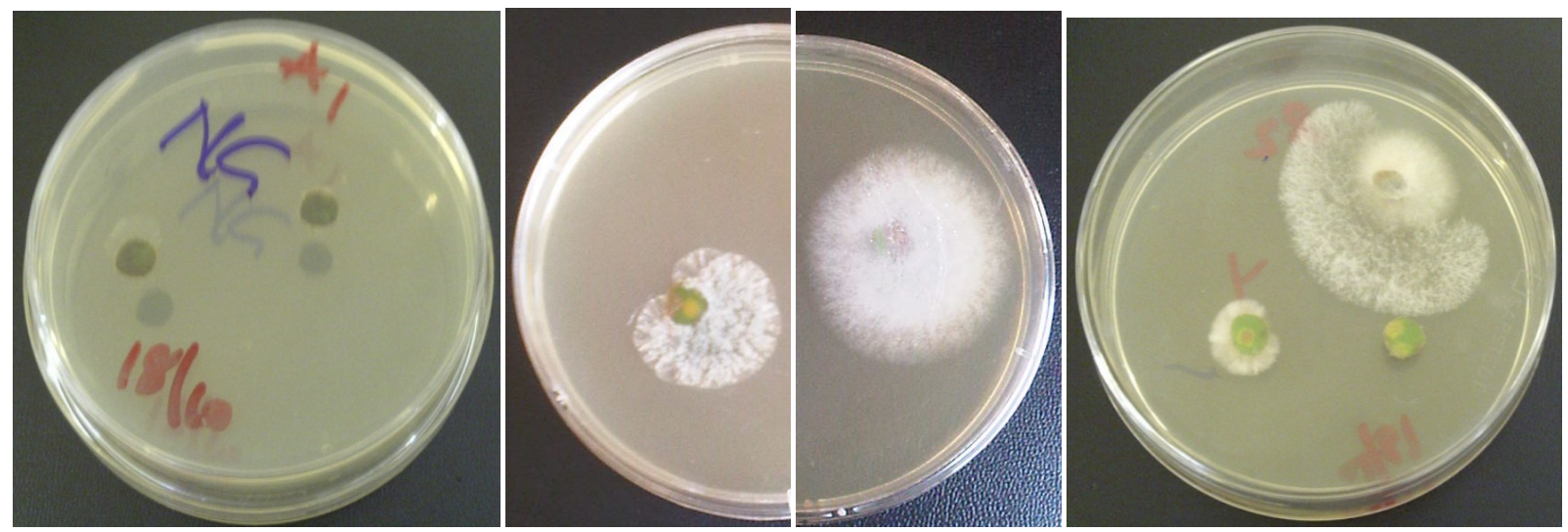

Figure 2. (A-D): Leaf discs of Codiaeum variegatum cultivars showing growths of pathogenic Fusarium. A) C. variegatum cv. royal did not show growth of Fusarium. B \& C) C. variegatum cv. royal-like and C. variegatum cv. punctatum both show growths of Fusarium lateritium D) C. variegatum cv. ovalifolium shows growth of $F$. semitectum
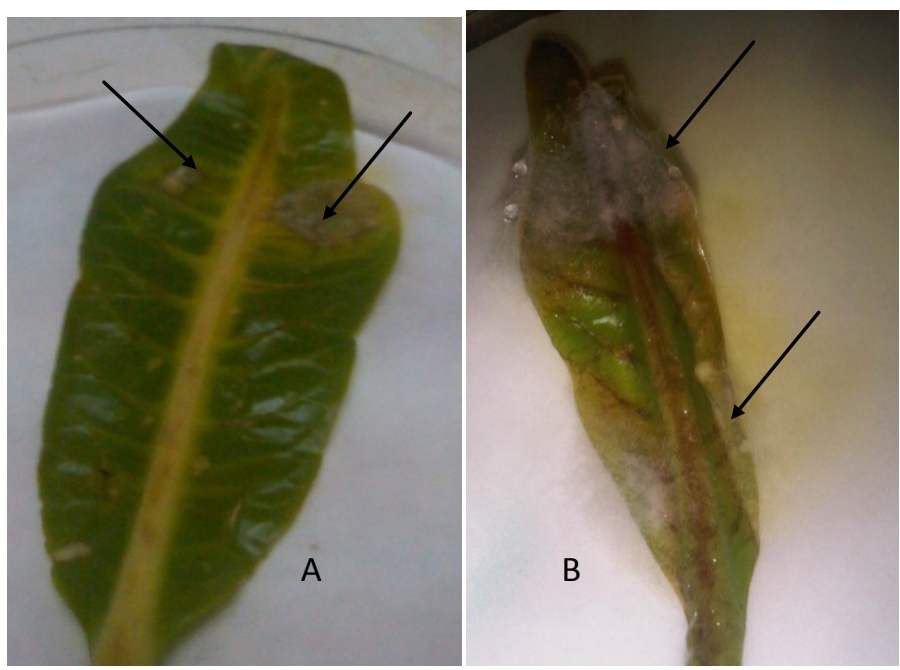

Figure 3. (A-B): Leaves of Codiaeum variegatum cultivars showing disease symptoms caused by Fusarium species. A) localized symptoms of mild discoloration and necrosis in C. variegatum cv. royal-like induced by sub-tissue growth of Fusarium lateritum. B) severe non localized chlorosis and necrosis in $C$. variegatum cv. ovalifolium induced by actively growing mass of $F$. semitectum
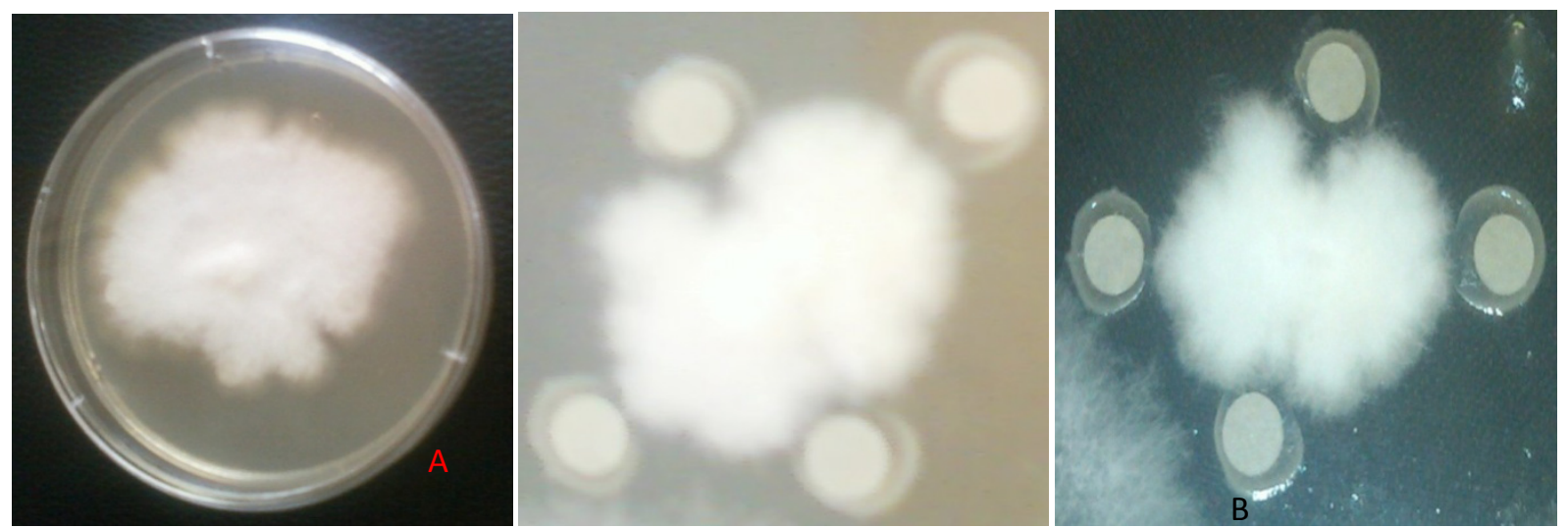

Figure 4. (A-C): Inhibit ory act ivity of lectin on Fusarium sem itectum isolated from C. variegatum cultivars. A) Controlplate: $0.15 \mathrm{M}$ buffered saline (NaCl) impregnated discs showed no inhibitory effect. B) Test plate: $10 \mu \mathrm{L}$ lect in solution impregnated discs showed antifungal activity. C) Test plate: $20 \mu \mathrm{L}$ lectin solution impregnated discs showed antifungal activity 


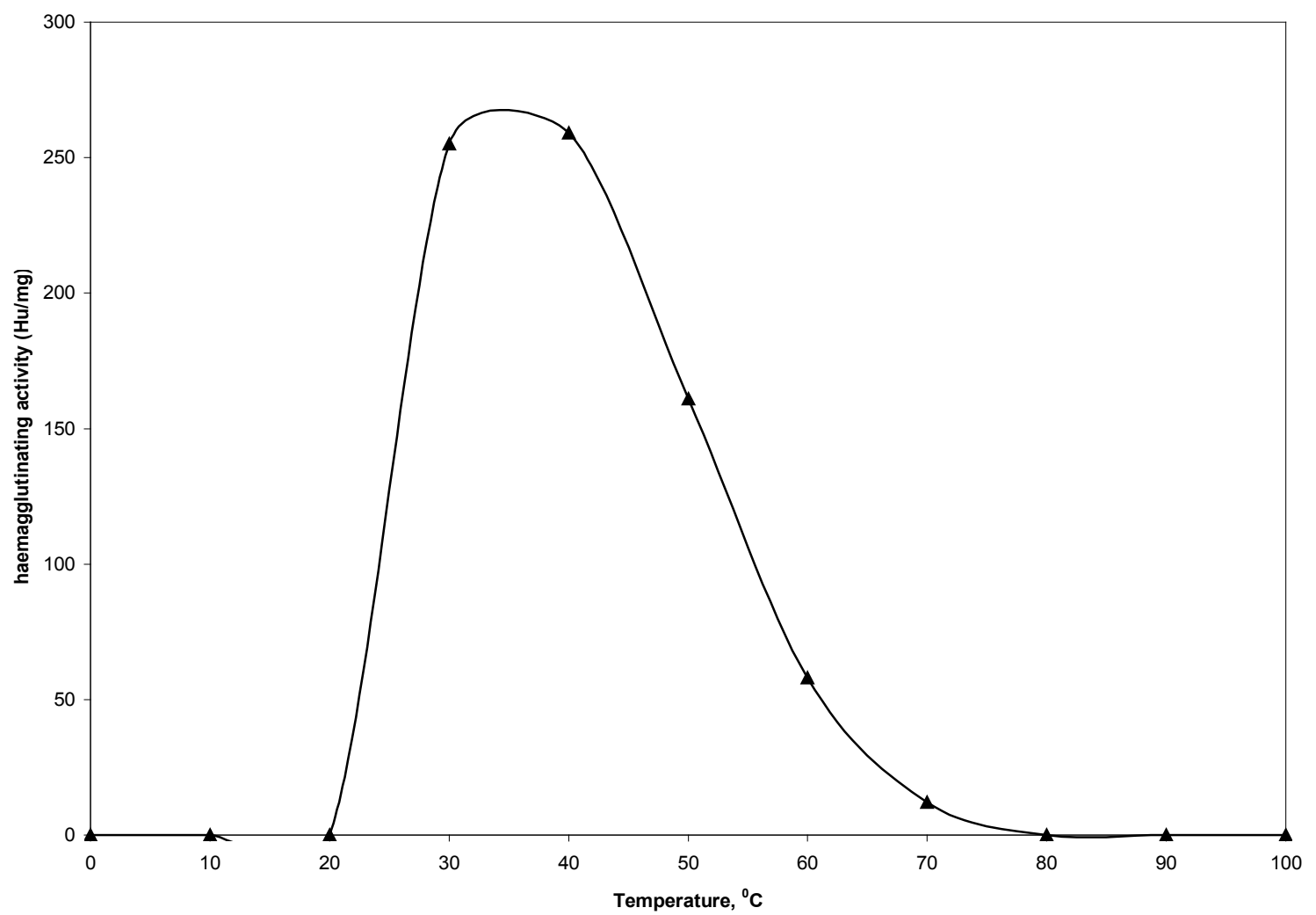

Figure 5. Effect of temperature on the heamagglutinating activity of Codiaeum variegatum cv. royal lect in

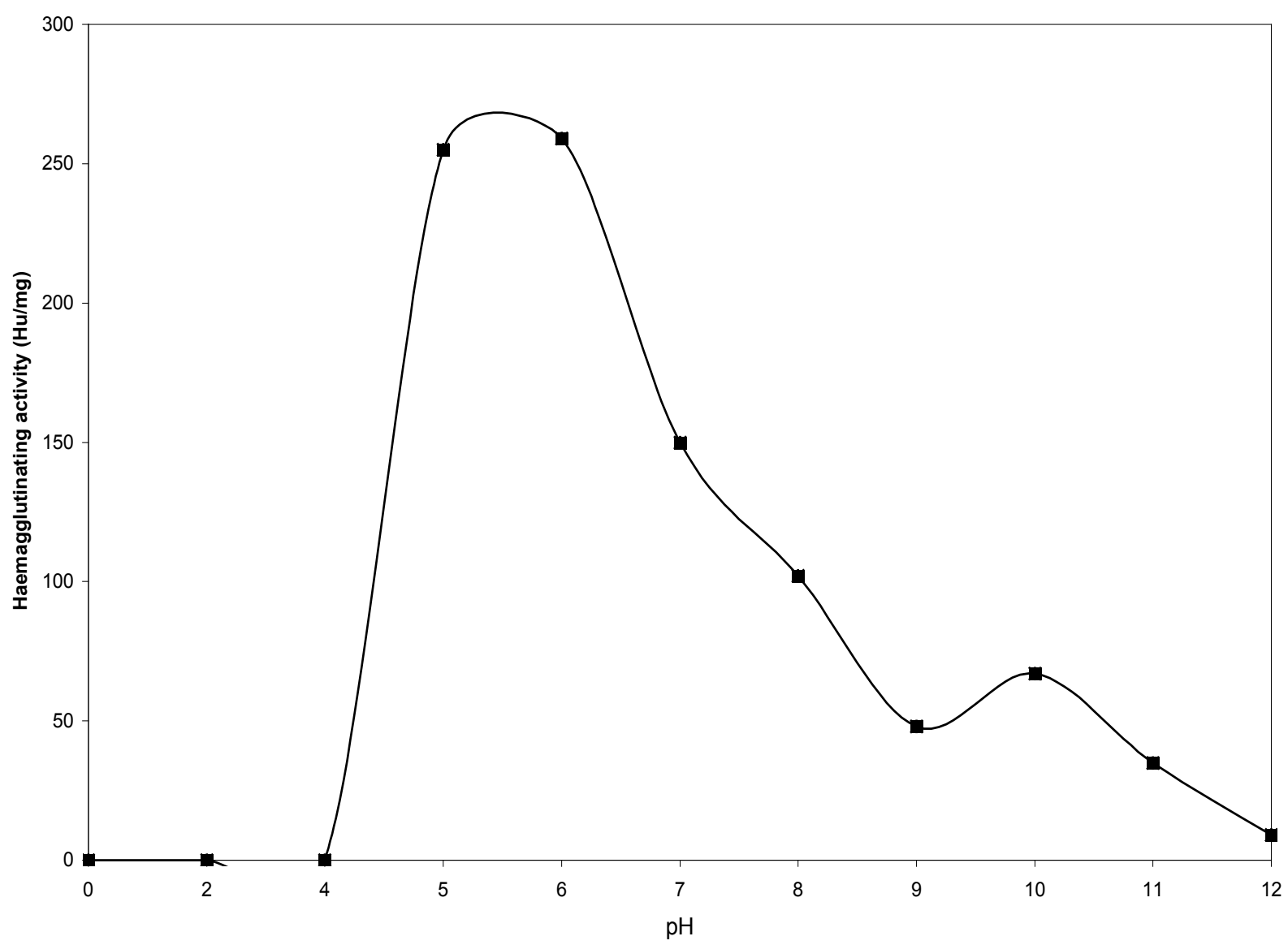

Figure 6. Effect of $\mathrm{pH}$ on the heamagglutinating act ivity of Codiaeum variegatum cv. royal lect in 


\section{Discussion}

In this study, the inhibitory activity of the lectin was not concentration dependent because there was no significant difference in the zones of inhibition caused by the lectin concentrations against the isolates although the zones produced by the $20 \mu \mathrm{L}$ lectin concentration were higher than those of the lower concentrations (data not shown). This finding supports the report of Awoyinka \& Dada (2011) and the wider inhibition zone may be due to an increased concentration translating into a higher antifungal activity. It has been suggested that plant lectins may have important roles according to their abundance, including in the immune defense, and also that lectins have been co-opted for several functions during evolution (24). The role of lectin in defense mechanis $m$ of plants may have evolved from the ability of the lectins to agglutinate and immobilize microorganisms. The supporting evidence for this proposed role in defense against pathogens falls into two categories: the presence of lectins at potential sites of invasion by infectious agents and the binding of lectins to various fungi and their ability to inhibit fungal growth and germination (26). The ability of $C$. variegatum lectin to inhibit fungal growth suggests that it may play an important role in immobilizing invading mic ro organism particularly fungal infections. The inhibition of fungal growth may have occurred through lectin binding to hyphae resulting in poor absorption of nutrients as well as by interference on spore germination process. This by interpretation means that resistance occurs as soon as the pathogen arrives on the leaves, a phenomenon referred to as a Systemic Acquired Resistance (SAR) due to the production of phytoallexins (27). When plants respond to attacks by either other plants especially lower plants called cryptogams, as pathogens or animals (herbivores) plants counter these threats with inherent defence systems that deter herbivory and or prevent infections or combat pathogens that infect. Defense systems could be physical, genetic, chemical or biochemical, that is, by ability of the plant to recognize invading pathogen; especially if unsuccess ful. Occasionally, a kind of co mpromise might have been evolved between the plants and pathogens. Under such cases, the pathogen simply ensures its own survival without severely damaging or killing the plant wholly or partially (27). The relationship between plant lect ins and phyloallexins though not studied in the investigation it might be another classical examp le of the fact that in plants, there are usually more alternative biochemical pathways evolved to regulate or control processes that ensure survival when plants are under stress, unlike what obtains in animals.

The isolation of Fusarium species from the diseased leaves of susceptible cultivars of $C$. variegatum investigated in this study (Fig. 3) is in line with a previous report (11). This study has shown that Fusarium species are major phytopathogens of the garden croton plant and their spectrum of pathogenicity is dependent on the presence or absence of lectins. The ability of lectin fro $m$ dis ease res istant C. variegatum to inhib it the Fusarium species suggests that it may play an important role in immobilizing invading microorganis ms particularly fungal infection. In addition, the carbohydrate-binding site of $C$. variegatum lectin may be vital in this activity, being responsible for the recognition of the fungi. The resistant cultivar of $C$. variegatum used in this study may be a suitable candidate for the prevention and treatment of fungal infections.

\section{Conclusions}

This study has shown that Fusarium species are major phytopathogens of the garden croton plant and their spectrum of pathogenicity is dependent on their Fructose binding specific lectins and their clinical importance. In addition, the resistant cultivar of $\mathrm{C}$. variegatum (cv. royal) used in this study may be a suitable candidate for the prevention and treatment of these fungal infections, through graftage and or hybridization. Although this study is not a comprehensive exerc ise on plant defenses against pathogens, the "lectins concept" is probably just one of these defenses.

\section{ACKNOWLEDGEMENTS}

We express our thanks particularly to Prof. (Mrs) Y. Makinde for the moral support and the Administrative Committee of Babcock University for the financial support on the Garden Croton Germplasm Project. The technical support in the microbiology laboratory by Akeredolu Bo la is also acknowledged.

\section{REFERENCES}

[1] Peng H, Lu H, Wang Y, Liu YH, Li CY, Meng L, Chen F, Bao JK, 2009. Clematis montana lectin, a novel mannose-binding lectin from traditional Chinese medicine with antiviral and apoptosis-inducing activities. Peptides 30: 1805-1815.

[2] Paiva PMG, Gomes FS, Napoleon TH, Saz RA, Correia MTS, Coelho LCB, 2010. Antimicrobial activity of secondary metabolites and lectins from plants. Applied Microbiology and Microbial Biotechnology 36: 396-404.

[3] Imberty A, Wimmerova M, Mitchell EP, Gilboa-Garber N, 2004. Structures of the lectins from Pseudomonas aeruginosa: an insight into the molecular basis for host glycan recognition. Microbes and Infection 6: 221-228.

[4] Naughton PJ, Grant G, Bardocz S, Pusztai A, 2000. Modulation of Salmonella infection by the lectins of Canavalia ensiformis (Con A) and Galanthus nivalis (GNA) in rat model in vivo. Journal of Applied Microbiology 88: 720-727.

[5] Schmidt MA, Riley LW, Benz I, 2003. Sweet new world: glycoproteins in bacterial pathogens. Trends in Microbiology 11 (12): 554-562. 
[6] Glandorf DCM, Sluis IV, Bakkers PA, Schippers B, 1994. Agglutination adherence and root colonization by fuorescent Pseudomonads. Applied and Environmental Microbiology 60: 1726-1733.

[7] Kwon YH, Epstein L, 1997. Isolation and composition of the 90KDa glycoprotein associated with adhesion of Nectria Haematococca macroconidia. Physiological and Molecular Plant Pathology 51 : 63-74.

[8] Tunlid A, Jansson HB, Nordbring-Hertz B, 1992. Fungal attachment to nematode. Mycological Research 96: 401-412.

[9] Sharon N, Lis H, 1998. Carbohydrate- specific proteins that mediate cellular recognition. Chemical Reviews 98: 637-674.

[10] Esan EB, Denton OA, Ayodele AE, Ogunwenmo KO, Fapohunda SO, 2005. The establishment of the Babcock University Garden Croton Germp lasm Repository Repository. Babcock University Academic Congregation Colloquium Series 2: 29-36.

[11] Fapohunda SO, Esan EB, O gunwenmo KO, Adedayo A, 2005. Report of Fusarium oxysporum on Codiaeum variegatum (L.) Blume (Euphorbiaceae) cultivars in Nigeria. actaSATECH 2 (1): 40-41.

[12] Dubey RC, Maheshwari DK, 2006. Practical Microbiology. $2^{\text {nd }}$ ed., S. Chand 7 Co. Ltd, Ram Nagar, New Delhi, p. 400.

[13] Nash SN, Snyder WC, 1962. Quantitative estimations by plate counts of propagules of the bean rot Fusarium in field soils. Phytopathology 52: 567-572.

[14] Leslie JF, Summerell, BA, 2006. The Fusarium Laboratory Manual. Iowa State University Press, Iowa. 400pp.

[15] Lis H, Belenky D, Rabinkov A, Sharon N, 1994. Purification of lectins and determination of their carbohydrate specificity. In Cell Biology. A laboratory handbook vol 3, Ed. by Cellis, C.E., Pp 332-338.

[16] Awoyinka OA, Dada OO, 2011. Partial purification and characterization of lectin from the seeds of Cissus poplunea. European Journal of Medicinal Plants 1 (4): 130-139.

[17] Trowbridge O, 1974. Isolation of a homodimeric lectin with antifungal and antiviral activities from red kidney bean
(Phaseolus vulgaris) seeds. Journal of Protein Chemistry 20: 367-375.

[18] Bing D, Wey and J, Satvitsky A, 1967. Hemagglutination with aldehyde- fixed erythrocytes for assay of antigens and antibodies . Proc. Soc. Exp.Bio. Med. 1244: 1166- 1170.

[19] Wang H, Gao J, Ng T, 2000. A new lectin with highly potent antihepatoma and antisarcoma activities from the oyster mushroom Pleurotus ostreatus. Biochemical \& Biophysical Resource Communication 275: 810-816.

[20] Bauer AW, Kirby MM, Sherris JC, Turck M, 1996. Antibiotic susceptibility testing by a standardized single disc method. American Journal of Clinical Pathology 45:493-496.

[21] Kuku A, Odekany in O, Adeniran K, Adewusi M, Olonade T, 2009. Purification of a mannose/glucose-specific lectin with antifungal activity from pepper seeds (Capsicum annum). African Journal of Biochemistry Research 3(6): 272-278.

[22] Patrick F, Mtui G, Mshandete A, Johansson G, Kivaisi A, 2007. Purification and characterization of a laccase from the basidiomycete Funalia trogii (Berk.) isolated in Tanzania. African Journal of Biochemistry Research 3 (5): 250-258.

[23] Perez G, 1995. Purification and characterization of a lectin from the seeds of Erythrina costaricensis. International Journal of Biochemistry and Cell Biology 27: 857-863.

[24] Pan S, Tang J, Gu X, 2010. Isolation and characterization of a novel fructose-binding lectin from the gill of bighead carp (Aristichthys nobilis). Vertininary Immunology and Immunopathology 133: 154-164.

[25] Alexander A, Bulgakov O, Kyung-ll P, Kwang- Sik C, HeeKy oung L, 2004. Purification and characterization of a lectin isolated from the manila clam Ruditapes philippinarium in Korea. Immunity 16: 487- 499.

[26] Sarinya C, Amorn P, Polkit S, Apichart K, 2011. Antifungal and antibacterial activities of lectin from the seeds of Archidendron jiringa Nielsen. Food Chemistry 126: 1025-1032.

[27] Campbell NA, Reece JB, Urry LA, Cain ML, Wasserman SA, Minorsky PV, Jackson RB, 2008. Biology $8^{\text {th }}$ ed., Pearson Int. Ed.,, San Francisco, Pp 321-536. 